\title{
СУЧАСНА УКРАЇНСЬКА ЛІНГВОГРАФІЯ: ТЕРМІНОЛОГІЧНЕ ПОЛЕ
}

ТЕТЯНА КОСМЕДА

Познанський університет імені Адама Міцкевича, Познань - Польща

tkosmeda@gmail.com

ЛІЛІЯ СОБОЛЬ

Дрогобицький державний педагогічний університет імені Івана Франка, Дрогобич - Україна

lilia.sobol@gmail.com

\section{WSPÓŁCZESNA UKRAIŃSKA LINGWOGRAFIA: POLE TERMINOLOGICZNE}

\author{
TETIANA KOSMEDA \\ Uniwersytet imienia Adama Mickiewicza, Poznań — Polska \\ LILIA SOBOL \\ Państwowy Uniwersytet Pedagogiczny imienia Iwana Franki w Drohobyczu, \\ Drohobycz — Ukraina
}

STRESZCZENIE. W artykule uaktualniono zagadnienie kształtowania się metajęzyka lingwografii jako odrębnej dziedziny nauki. Podkreślono znaczenie współzależności formy i treści, przejawiającej się w języku pisanym, zwłaszcza w dyskursach artystycznym i publicystycznym, a ostatnimi czasy również w języku internetowym. Opisano związki systemowe terminów lingwografii, wskazano kwestie sporne oraz perspektywy rozwoju metajęzyka danej nauki.

\section{MODERN UKRAINIAN LINGUO-GRAPHIC STUDIES: TERMINOLOGICAL ASPECT}

\author{
TETIANA KOSMEDA \\ Adam Mickiewicz University, Poznań — Poland \\ LILIYA SOBOL \\ Drohobych Ivan Franko State Pedagogical University, Drohobych — Ukraine
}

ABSTRACT. The article focuses on the actualization of the problem of the linguo-graphic studies metalanguage formation as a separate science which is in a state of a constant development. The importance of the correlation of the form and the content has been emphasized. This correlation functions in a written speech, in particular: fiction and publicistic discourse and recently in the I-net speech. The system connections of the linguo-graphic studies terms have been described, the problematic items and the development perspectives of the metalanguage have been determined.

Л

ітери алфавіту, звуко-букви, графеми як основні одиниці лінгвографії, графіки (графетики) виконують, як і будь-які інші мовні знаки, функцію символу, передусім і такого, через який можна здійснювати “національну мобілізацію”". Вони мають значний ідеологічний та емоційний вплив на носіїв

${ }^{1}$ А. Штекен брок, Лингвонационализм. Языковая рефлексия как посредник коллективной самоидентификации в Германии (1617-1945) (выдержки из книги), [в:] От лингвистики к мифу: Лингвистическая культурология в поисках “этнической семантики”, сб. статей, сост. А. В. Павлова, 2013, с. 62-94. 
мови. Крім того, графемні та графічні знаки можуть моделювати систему прагматичних смислів. Це знаки відповідної лінгвокультури, що виражають “дух" кожної конкретної мови, адже “форма" є опозитивним корелятом "змісту". Зовнішня форма мовних одиниць у різних мовах не збігається, точніше, може збігатися частково, що простежуємо і в споріднених мовах.

Сучасна німецька дослідниця А. Штекенброк наголошує: „Рідна мова сама собою творить історію своїх носіїв: кожне ії слово, кожна буква й кожний звук це свідчення «глибинної сутності», «давньої історії», «величі», «розуму», «морального начала», «духовності» й «душевності» людей, які розмовляють цією мовою" (перекл. автор. - Т. К.) ${ }^{2}$. Зрозуміло, що зовнішня форма знаків часто стає "смислотвірним фактором" і генерує лінгвоспецифічні, тобто безпосередньо зумовлені особливостями конкретної мови смисли (рима в поезії, утворення фразеологічних одиниць, гра слів, текстуалізовані вербальні асоціації, додатковий стилістико-прагматичний ефект у процесі вживання територіальних чи соціальних варіантів вимови тощо). Зовнішня форма, зрозуміло, може призводити до значних утруднень у міжкультурній комунікації, передусім у міжкультурній трансляції․

Українські дослідники приділяють значну увагу вивченню проблем графіки, ширше - лінгвографії, зокрема теоретичним питанням мотивації доцільного використання графіки й пунктуації, певних шрифтів та інших елементів поліграфії. До таких мовознавців належать передусім сучасні українські вчені, як-от: О. Білецька ${ }^{4}$, Т. Видайчук ${ }^{5}$, П. Донець ${ }^{6}$, А. Загнітко чук ${ }^{9}$, Л. Українець ${ }^{10}$, І. Фаріон ${ }^{11}$, Л. Чернюх ${ }^{12}$ та ін. Метологічною базою цих досліджень стали праці класиків мовознавства, зокрема О. Потебні, Л. Булаховського, П. Фортунатова, Ю. Шевельова та ін. Л. Булаховський, услід за П. Реформатським, ще в сер. XX ст. актуалізував проблематику лінгвографії, зміст якої — „специфіка письмового виразу в його відношенні до можливого поліграфічного оформлення тексту. Ця специфіка [...] далеко не така обмежена, як

${ }^{2}$ Там же, с. 65.

${ }^{3}$ П. Дон е , Основы общей теории межкультурной коммуникации: научный статус, понятийный аппарат, языковой и неязыковой аспекты, вопросы этики и дидактики, Харьков 2001, c. 94 .

4 О.В.Білець ка, Графічна форма постмодерністського художнього тексту крізь призму графічної лінгвістики, [в:] „Нова філологія”, зб. наук. праць, наук. ред. В. М. Манакін, Запоріжжя 2014, № 60 .

5 Т. В и дайчук, Українська живомовна фонетика $і$ кирилична графіка в дослідженнях Івана Франка, [в:] Іван Франко: дух, наука, думка, воля. Матер. Міжнар. наук. конгр., присвяч. 150-річчю від дня народж. Івана Франка (Львів, 27 верес. - 1 жовт. 2006 р.), Львів 2010, т. 2: Проблеми мовознавства.

${ }^{6}$ П. Донец, указ. источн. 2012.

А. П. Загнітко, Словник сучасної лінгвістики: поняття і терміни, у 4 томах, Донецьк

8 Л. Л. Макарук, Графічна лінгвістика: становлення, сучасний стан та перспективи розвитку, [в:] „Іноземна філологія”, укр. наук. зб. Львів. нац. ун-ту ім. І. Франка, гол. ред. А. Й. Паславська, Львів 2013, вип. 125.

9 В. В. Нім чу к, Про графіку та правопис як елементи етнічної культури: історія $\tau$, [в:] „Мовознавство”, Київ 1990, № 6.

10 Л. Ф. Українець, Фонетична конотаиія в украӥнській поетичній мові XX-XXI ст.: семантико-прагматичний вимір, Київ-Полтава 2014.

${ }^{11}$ I. Д. Фаріон, Мовна краса і сила: Суспільно-креативна роль украйнської мови в XIсередині XIX ст., Львів 2011.

12 Л. Д. Чернюх, Лінгвальні особливості сучасної словацької реклами, автореф. дис. ... канд. філол. наук, Київ 2014. 
може здаватися із самих умоглядних позицій, отже, і практичну користь від роботи над нею аж ніяк не слід недооцінювати" "13.

Однак, як видається, і сьогодні лінгвографія ще не знайшла належного розвитку в мовознавчій теорії, хоч функції графем, з одного боку, розширюються, а „розвинені системи письма, на відміну від примітивних, виявляють свій зв'язок і залежність від характеру відповідних мов, що ними обслуговуються"'14.

Як відзначають українські вчені, лінгвографія не має окресленого понятійного апарату, методологічної бази, зокрема невизначеними залишаються іiї об'єкт, предмет, методи, завдання і под. ${ }^{15}$, що потребує конкретної й ретельної роботи, осмислення й узагальнення. Немає єдиного погляду навіть на назву науки, про яку йдеться, оскільки, крім терміна лінгвографія, функціюють також графічна лінгвістика, граматологія, граматографія, графологія, філографія, інфографіка. Мовознавці переконані, що лінгвографію (надаємо перевагу саме цьому терміну як найбільш поширеному) можна поділити на кілька розділів, ураховуючи структурне розмаїття ії одиниць, характер співвідношення $з$ нелінгвістичними сферами, способи аналізу, а кожний розділ може мати ще й підрозділи ${ }^{16}$. Однозначно можна стверджувати, що лінгвографія - це комnлексна наука про письмо, яка має низку “білих" плям передусім методологічного характеру.

Термін "лінгвографія", чи “графічна лінгвістика", називають “парасольковим”, оскільки він охоплює суміжні наукові напрями, що мають спільний об'єкт дослідження - письмо, однак різняться своїм дослідницьким предметом ${ }^{17}$.

Приділяючи особливу увагу проблемам лінгвографії, Л. Булаховський писав, що „панівна (типова) графічна форма письмових знаків певної цивілізації $\epsilon$, звичайно, умовна і визнається нацією внаслідок тривалої традиції' 18 .

Графіка, як зауважувалося, без заперечень визнається важливим соціальноідеологічним чинником впливу на мовців. Саме тому впродовж тривалого часу існування писемності, зокрема функціювання кирилиці, українського алфавіту, що на ній базується, відбуваються “азбучні війни”, простежується намагання нав'язати українській лінгвокультурі латиницю чи лінгвокультурам, що базуються на латиниці, - кирилицю, що, скажімо, практикувала Росія щодо Польщі, напр., у XIX - на поч. XX ст.

В. Німчук у праці Про графіку та правопис як елементи етнічної культури: icmopiя $t$ перефразовує слова Т. Шевченка і пише: „Ну що, здавалося б, літери? Писемні знаки та й більш нічого!” (Див. також назву статті I. Фаріон „Ну щзо б, здавалося, слова...”). Маючи на меті підкреслити значущість писемності, що нерозривно пов'язана з буквами, графемами чи звуко-буквами, названий учений пише, що існує „якнайтісніший зв'язок системи мови і системи писемності в людській уяві", адже будь-яка мова засвоюється насамперед акустично та візуально (текст, графічні знаки) ${ }^{19}$, що не викликає заперечень. т. 1, c. 90 .

${ }_{13}$ Л. А. Булаховський, Лінгвографiя, [в:] Його ж, Вибр. пращ⿻і, в 5 томах, Київ 1975,

${ }^{14}$ Там само.

${ }^{15}$ О.В.Білецька, Становлення графічної лінгвістики як комплексної науки: аналітичний огляд, [в:] „Наук. вісн. Херсон. держ. ун-ту, сер. Лінгвістика”, гол. ред. Н. П. Матвеє ва, Херсон 2013, с. 18-28.

${ }^{16}$ Л. Л. Макарук, зазнач. джер.

${ }^{17} \mathrm{O}$. В.Білецька , Становлення графічної лінгвістики як комплексної науки...

${ }^{18}$ Л. А. Булаховський, Лінгвографія...

${ }^{19}$ В. В. Німчук, зазнач. джер. 
Знаки пунктуації належать до допоміжних графічних знаків, які ще прийнято називати нелітерними знаками. Вони вживаються для членування писемного тексту й також $є$ частиною графічної системи певної мови, та „обслуговують ті аспекти писемної мови", що не передаються буквами відповідно до чинних правил орфографії та пунктуації ${ }^{20}$. „Попри те, що нелітерні знаки є одиницями графічного рівня і не мають звукового аналога...”, вони виконують такі функції: фонографічну, змісторозрізнювальну, графомарковану, прагматичну тощо ${ }^{21}$.

Отже, наголосимо, що писемна мова кожного народу є насамперед системою графічних знаків (основних і допоміжних), що виникла на відповідному рівні людського поступу й розвивалася протягом століть. Система звукових знаків репрезентована буквами, що розміщені в певному порядку, утворюючи алфавіт, азбуку, чи абетку (абецадло), - основні графічні знаки.

Деякі вчені вважають, що необхідно розрізняти поняття буква (літера) і графема, наголошуючи, що графема - це „найменша смислорозрізнювальна одиниця писемної мови, яка відповідає фонемі в усному мовленні"’22, напр., у слові сіль - 4 букви, але 3 графеми. „Буква має значення, обумовлене співвіднесенням iii з фонемою чи фонемами, яке визначають за сильною позицією фонеми"2з. Термін “графема” ввів у лінгвістичний обіг І. Бодуен де Куртене саме „з метою зорової фіксації образу фонеми". Цьому передувала орфографічна дискусія, організована П. Фортунатовим, наслідком якої стала орфографічна реформа 1917 року $^{24}$.

Однак, як доводить аналіз наукової літератури, словників лінгвістичних термінів, графема - багатозначний термін, оскільки його використовують і на означення будь-якого графічного накреслення, будь-якої графічної одиниці, включаючи й букви, і знак наголосу, розділові знаки, пробіли, відступи, прийоми скорочення слів і речень (А. Загнітко, О. Селіванова). У писемному варіанті графеми бувають друковані й рукописні, великі й малі. Система основних графем української мови містить, як відомо, 33 літери, хоч упродовж її становлення ця кількість була більшою чи меншою. „Вибір графем на письмі визначається їхньою синтагматикою (поєднанням букв у тексті), правилами орфографії та пунктуації’25. Графему розглядають і як співвідношення між буквою і звуком: у цьому разі використовують синонімічний термін звуко-буква, що, вочевидь, мотивовано характером письма, що визначається як звуко-буквене. Отже, цілком логічну одиницю такого письма можна називати звуко-буквою (А. Загнітко, Т. Космеда, І. Фаріон).

Отже, як видається, має місце широкий і вузький підходи до розуміння терміна графема. Це необхідно враховувати, оскільки графеміку розглядають і як сукупність усіх графічних знаків.

20 Див. про це: О. В. Станіслав, Функиіональні характеристики нелітерних знаків франиузької орфографії, Луцьк 2009.

${ }^{21}$ Там само.

${ }^{22}$ Сучасна украӥнська мова. Фонетика. Фонологія. Орфоепія. Графіка, навч. посіб., за ред. М. М. Фащен но, Київ 2010, с. 134.

${ }^{23}$ Там само, с. 241.

24 О. О. Селів ван ов а, Лінгвістична енциклопедія, Полтава 2010, с. 108; Большой энщиклопедический словарь, гл. ред. В. Н. Ярце в а, Москва 1998, с. 117-118.

${ }_{25}$ Украйнська мова: енциклопедія, редкол.: В. М. Русанівський, О.О.Тараненко (співгол.), М. П. Зяблюк та ін., Київ 2000, с. 119; А. П. Загнітко, зазнач. джер., т. 1, с. 177; О. О. Селіванова, зазнач. джер., с. 108. 
Сукупність літер, що розміщені у відповідно прийнятому порядку, - це aлфавіт. Алфавіт, як відомо, слово грецького походження (створене від назви перших літер, власне, грецького алфавіту способом складання). В українській мові $€$ кілька синонімів до цього слова: перше - азбука, що походить від поєднання давньослов'янських літер аз і буки (складання; від цього слова походить і лексема азбуковник - своєрідний словник-довідник, у якому статті 3 різних галузей знання розміщувалися за алфавітним принципом: спочатку в них подавалися слова іншомовного походження 3 докладним розкриттям значення, біблійно-церковна символіка (XIII - XIV ст.), а далі - світська інформація зі значенням джерел (XVI - XVII ст.); поширювалися азбуковни$\kappa u$ переважно в рукописному вигляді й призначалися передусім учням ${ }^{26}$; друге - абетка (складання із суфіксацією), створене за назвами літер сучасного алфавіту. У XIX ст. в західній частині України алфавіт називали абецадлом: тут виразно відчувається польський вплив, тобто за першими літерами латинського алфавіту $(\boldsymbol{a}, \boldsymbol{b}$ і $\boldsymbol{c})$.

Номінації самого алфавіту містять назви відповідних графем, оскільки термін графема використовують і на позначення букви, літери (А. Загнітко, О. Селіванова). У мовній свідомості носіїв кожної лінгвокультури як “пам'ять давнини" зафіксовані й ті назви літер, що на сьогодні вийшли з ужитку: ідеться, зокрема, про назви $\boldsymbol{a}$, буки і под. У цьому разі назви графем є мотивувальними основами творення слів: вони набули статусу кореневих морфем, тобто має місце не лише лексикалізація, але й семантизація назв букв. Літери не лише стають словотвірною базою для творення інших слів, але й набувають здатності передавати відповідне значення, що фіксується за ними у свідомості мовців. Інколи воно, як зазначалося, пов'язане з внутрішньою формою літери, протобукви.

Уважаємо, що необхідно ввести в лінгвістичний обіг терміни лексикалізація і семантизація графем на означення відповідних процесів, а також графемиісторизми для номінації тих літер, що вийшли 3 ужитку внаслідок реформ графіки (напр. юс великий, юс малий, ять та ін.), та архайчні номінації графем для окреслення літер, у яких змінилася назва (напр. добро - де, мисліте $\boldsymbol{e} \boldsymbol{м}$ і под.), однак вони не вийшли з ужитку. Крім того, для номінації графем, що вилучені з графічної системи внаслідок політичних чинників, уведено образний термін “репресована графема": ідеться про літеру $\boldsymbol{\tau}$, що була вилучена з українського алфавіту, але в часи незалежності України повернута.

Нефіксований у сучасних лінгвістичних термінологічних словниках і згадуваний вище термін звуко-буква, однак його використовують у мовознавчому науковому дискурсі, хоч і в різних графічних варіантах — звуко-буква і звукобуква (Див., напр.: Т. Космеда, І. Фаріон ${ }^{27}$ ). Уважаємо, як зазначалося, що цей термін зручний для номінації явища, що характеризує особливості вживання букви з урахуванням специфіки іï фонетичного омовлення, специфіки звукобуквеного письма.

Крім традиційних функцій, які виконують графеми в мові, можна виділити і їхні нові функції, пов'язані з тим, що назва літери може не лише

${ }^{26}$ Р. Т. Гром’як, Ю. І. Ковалів, Літературознавчий словник-довідник, Київ 1997, с. 18.

${ }_{27}^{27}$ Т. А. Космеда, Потенціал сучасної лексикографії і прагмалінгвістики в осмисленні статусу кононативних графем, [в:] „Слово и словарь. Vocabulum et vocabularium”, сб. науч. трудов по лексикогр., под ред. В.В.Дубичинского и Т. Ройтера, Харьков 2011, вып. 12, с. 123-127; І. Д. Фаріон, Ну щзо б, здавалося, слова..., [в:] „Літературний Львів”, Львів 2005, c. 19-21. 
лексикалізуватися і семантизуватися, тобто набути статусу самостійної лексеми, отримати значення чи здатність виражати певний смисл, але й, функціюючи в дискурсивному просторі, мовленні, зафіксувати певні конотації, зреалізувати здатність виконувати систему прагматичних функцій (виражати емоції, почуття, експресію та ін.).

Графему (графеміку загалом) слід розглядати і як текстову категорію, оскільки в лінгвостилістиці, як відомо, існує низка прийомів уживання основних та допоміжних графічних знаків для моделювання виразності, образності тексту, його орнаменталіки, ідеться навіть про функцію інтимізації (графемна чи графічна інтимізачія), яку реалізують саме графеми ${ }^{28}$, що вивчається в межах лінгвографії. Очевидно, графеми, які виконують цю функцію, можна номінувати графемами-інтимізаторами. Власне явище інтимізації мовлення А. Загнітко пояснює як „мовні засоби і прийоми, що передають настрій мовця, наближають автора до читача як до співрозмовника; стилістичний прийом у художньому мовленні, коли автор прагне увійти у ближчий комунікативний контакт 3 читачем, робить його співрозмовником, звертається до нього, пояснюючи йому свої переживання, думки і запрошуючи стежити за оповіддю"29. Графічні засоби також можуть виконувати цю функцію.

Слушно уважається також, що „використання графічних засобів дає змогу збільшити кількість каналів, якими інформація передається адресатові, що сприяє iї ефективному засвоєнню. Адресатові не лише надають додаткову інформацію, а залучають суб'єкта сприйняття інформації до індивідуальноавторської картини світу, його комунікативного простору, системи авторського мислення та, відповідно, до системи тексту, який сприймається" ${ }^{\prime 3}$.

А. Палійчук актуалізує проблему розрізнення словесного тексту і текcmу візуального, порівн.: „Словесний текст — це графічно зафіксована мова, організована відповідно до граматичних правил. Під візуальним текстом [...] розуміємо графічне виконання словесного тексту, що включає графічний поділ тексту, використання різних гарнітур шрифту, наочний матеріал ілюстративного характеру тощо"з1.

I. Арнольд пропонує термін графічна образність ${ }^{32}$, під яким розуміє прийом поділу тексту на абзаци або вірша на строфи за певними принципами, тобто йдеться про фігурну поезію або зорову поезію. Ї̈̈ ще називають візуальною, або графічною. Зорова поезія може мати цілком самодостатній зміст, що надає твору додаткової поетичної енергії. Зорову поезію розглядають як поетичний засіб на рівні просодії і як троп тексту. Відомо, що елементи зорової поезії з'явилися ще в літературі Київської Русі (декоративне оформлення літер, фігурний текст, написи на предметах), однак як самостійне явище вона почала формуватися з др. пол. XVI ст. На сьогодні зорова поезія розвила систему жанрів: розрізняють

\footnotetext{
${ }^{28}$ Див., напр., А.Л.Палі йчук, Графічні засоби інтимізаиії в англомовному художньому дискурсі, [в:] „Наук. вісн. Волин. ун-ту ім. Лесі Українки, сер.: Філол. науки. Мовознавство”, Луцьк 2011, № 5, с. 102-105.

29 А. П. Загнітко, зазнач. джер., т. 1, с. 385-386; А. Горнятко-Шумилович, Т. А. Ко сме да, Феномен креативності Василя Симоненка: літературознавчий талінгвістичний аспекти, за заг. ред. проф. Т. Косм еди, Познань 2016.

${ }^{30}$ А. Л. Палійчук, зазнач. джер., с. 103.

31 Там само, с. 103; С. С. Данилюк, Використання графічних засобів у текстах електронної пошти, [в:] „Наук. записки. Сер. Філологія”, зб. наук. статей, Вінниця 2009, с. 216-219. 2002 .

${ }^{32}$ И. В.Арн ольд, Стилистика. Современный английский язык, учеб. для вузов, Москва
} 
вірш фігурний, узгоджений, співвідносний, онограматичний, квадратний, числовий, віри-лабіринт, ракові вірші та ін. Зорову поезію розвивали модерністи й продовжують удосконалювати постмодерністи ${ }^{33}$.

Загальновідомо, що прагматична функція - це функція впливу на адресата. Графеми, що лексикалізуються й семантизуються, репрезентують сильну позицію функціювання, що сприяє моделюванню прагматичних смислів і відповідних функцій. Л. Булаховський так характеризує прагматичну функцію слова, проектуючи це на художній текст: „Теорія художньої мови цінна, зокрема, тим, що, на відміну від звичайних інтелектуальних настанов семантики, далеко більше зосереджує увагу на емоціональній стороні мови. Вона максимально зважає на те, що емоціональні елементи, різні відміни відчувань пронизують мову і що, отже, іiі правильно можна уявити собі тільки невідривно від них. Коли ми говоримо, ми не тільки висловлюємо наші міркування та розповідаємо, а й виливаємо в словах почуття, що так або інакше супроводжують наші міркування та уявлення. [...] Виражальними засобами при цьому для нас є і добір синонімічних слів та форм, і особливості порядку слів, і психологічні особливості окремих звуків, і безкрая різноманітність відтінків тембру, коли вони виходять за межі найтиповіших якісних одмінностей звуків мови, і вся ритмомелодична сторона мови з їі варіаціями щодо сили, тону, довготи, паузи. Увага до всього цього - умова належного освітлення мовних засобів художнього твору і розуміння його критиком..." ${ }^{34}$. Додамо, що все сказане проектується на основні й допоміжні графеми.

Літери, як наголошувалося, можуть бути репрезентовані різними способами, може актуалізуватися їхня архаїчна чи нова назва (лексикалізація), буква може набувати в мовному просторі відповідного смислу, значення (семантизація), крім того, може бути вжита в незвичній формі (велика літера замість малої (капіталізація) чи навпаки та ін.) і функції з порушенням чинної графічної норми, що уможливлює створення графічної образності, напр.: ...нам залишилось пірнути у води / $і$ наче стікс переплисти йордан ${ }^{35}$.

Вище зауважувалося, що пунктуаційні знаки можна інтерпретувати не на основі традиційних принципів пунктуації, а на основі авторського чуття, авторського замислу. У такому разі мовець може порушувати чинну норму пунктуації 3 актуалізацією пунктуаційної прагматичної норми. Напр., постмодерніст I. Андрусяк у вірші Катерина Білокур. Автопортрет виділяє вставне слово не комами, що зумовлено пунктуаційною нормою, а тире, порівн.: Бо туту уже осінь - розколиш горіх — / i там уже осінь / $i$ сонячні зайчики - бачите босі / біжать до порога - а як за поріг ${ }^{36}$.

Доведено, що письменники часто “полюбляють” певні розділові знаки, дещо ними “зловживаючи”, надаючи їм перевагу, укладаючи в них індивідуальноавторський смисл. Традиційно виокремлюють індивідуально-авторські пунктуаційні знаки, що є наслідком індивідуально-авторської інтерпретації смислу тексту. Очевидно, має право на існування й образний термін “улюблений авторський пунктуаиійний знак” - знак, що переважає в тексті, дискурсі

${ }^{33}$ А. К. Мой с іє н ко, У світі візуальної поезї, [в:] Філологічні студії: поетика, лінгвістика, літературознавство, літературна критика, перекладознавство, інтерв'ю, публіцистика, КиївУмань 2015, с. 232-244.

34 Л. А. Булаховськи й, Теорія художньої мови, [в:] Його ж, Вибр. прачі, у 5 томах, Київ 1975 , т. 1 , с. $84-85$.

35 Ю. Іздрик, Календар любові: поезія, Львів 2015, с. 311.

36 I. Андрусяк, Писати мисліте, Київ 2008, с. 6. 
того чи того автора, який репрезентує певні авторські інтенції - оцінки, емоції, смисли і под. - i виокремлюється на тлі інших індивідуально-авторських пунктуаційних знаків (напр., відомо, що найбільш поширеним, "улюбленим" знаком пунктуації М. Горького було тире, про що пише, напр., Д. Розенталь, називаючи тире “пристрастю” М. Горького $\left.{ }^{37}\right)$.

Унаслідок аналізу метамови сучасної графіки (лінгвографії) на основі вибірки термінів з найбільш авторитетних сучасних термінологічних словників чи енциклопедій та довідкової літератури (Див.: Д. Ганич та I. Олійник ${ }^{38}$, енциклопедія Українська мова ${ }^{39}$, А. Загнітко ${ }^{40}$, О. Селіванова ${ }^{41}$ та ін.), а також грунтовної наукової літератури з розглядуваної проблеми ${ }^{42}$, було зібрано понад 200 дефініцій.

Уважаємо, що метамову лінгвографії, графіки можна розширити, доповнивши деякими необхідними термінами, які на сьогодні ще слід кваліфікувати як оказіональні (графеми-історизми, букви-історизми чи графеми-архаїзми, букви-архаїзми, прагматика назви літери, прагматична графеміка, лексикалізачія літери (букви), семантизачія літери (букви) та ін.). Порівн.: алфавіт, абетка, абецадло, азбука, "азбучна війна", апостроф, архаїчні номінаиії графем, астронім, буква, буквений запис, варіанти лапок, велика буква (літера), виділювальні розділові знаки за функиійною класифікачією, викличник, винесені надрядкові букви, відокремлювальний розділовий знак, відступ, відчуження на рівні графем, внутрішня форма букви, глаголиия, граф (графа), графема, графеміка, графіка, графічна інтимізація, графічна лінгвістика, графічна норма, графічна система, графічна структура тексту, графічне накреслення, графічний знак, графічний малюнок, графічний рівень, "двоєточіє”, двокрапка, дефіс, дефісаиія, дефісне написання иілого слова, діакритичний знак, “драгоманівка”, друкованалітера (буква), друкованийграфічнийзнак, допоміжна графема, дужки, емоціональний розділовий знак, “желехівка”, заокруглені дуж$\kappa и$, “запятая”, застарілі назви графем, звуковий аналог, знак наголосу, знак питання, знак переносу, знак оклику, зорова поезія, зорова фіксаиія образу фонеми, інтерпункція, кирилиия, інтимізувальна графіка, крапка, крапка з комою, крапки, “кулішівка", лапки, лінгвографія, літера, латиниия, “максимовичівка", мала літера, назва графеми (літери), наголос, нелітерний знак, писемна мова, письмо, орфографічна дискусія, орфографічна норма, орфографічна реформа, орфографія, орфограма, парний видільний розділовий знак, писемність, писемний варіант графеми, писемний графічний знак, писемність, письмо, півустав, пояснювально-роз'яснювальна функиія розділового знака, правила орфографiї, правила пунктуачії, прийом скорочення слів і речень, пробіл, протобуква, прямі дужки, пунктограма, пунктуаційний знак, пунктуаиія, "репресована графема (літера)”, "розділка”, розділовий знак, рукописна літера (буква), семантизація літери, синтагматика графем, система графічних знаків, скоропис, словесний наголос, тип письма, тире, “удивная”, устав, фігурні дужки, “фірмовий

37 Д. Э. Розенталь, Справочник по пунктуаичии, Москва 1997.

${ }_{38}$ Д. І. Ганич, І.С.Олійник, Словник лінгвістичних термінів, Київ 1985.

39 Украйнська мова: енциклопедія, редкол.: В. М. Русанівський, О. О. Тараненко (співгол.), М. П. Зяблюк та ін., Київ 2000.

${ }^{40}$ А. П. Загнітко, зазнач. джер.

${ }^{41}$ О. О. Селіванова, зазнач. джер.

42 Л. А. Булаховськи й, Лінгвографія, [в:] Його ж, Вибр. праиі, т. 1, с. 90; I. Огієнко, Рідна мова, Київ 2010; А. Нелюб а, Словотворчість незалежної Украйни. 1991-2011, Харків 2012. 
знак” автора, фонетико-графічна стилістична фігура, форматив, функиї двокрапки, функиії дужок, функиії крапки, функиії лапок, функиії знака оклику, функції знака питання, функції тире, функиія нелітерного знака фонографічна, функція нелітерного знака змісторозрізнювальна, функція нелітерного знака графомаркована, хрестик, “ярижка” та деякі інші.

У цей перелік необхідно ввести й терміни лінгвостилістики, лінгвопоетики, зокрема ті, що окреслюють поняття фоностилістики (це на сьогодні докладно схарактеризовано в монографічній праці Л. Українець $\left.{ }^{43}\right)$, чи, можливо, графічної стилістики (як видається, останній термін має право на існування у зв'язку з актуалізацією випадків створення стилістичних ефектів за допомогою маніпуляції графічними засобами мови), метамова якої повинна містити назви стилістичних фігур і прийомів, що грунтуються на маніпуляції графемами та їхніми окресленнями, напр.: алітерація, амфіболія, анаграма, анафора, апокопа, апосіопеза, асонанс, афереза, графічний евфемізм, графон, дефісаиія, злиття, капіталізація, квотація, логогриф, паренсесиз, поетична графіка, прийоми пунктуачійної гри (повна відсутність пунктуачійних знаків, надмірне їх використання або зумисне використання лише окремих розділових знаків), прозіопесис, протезис або протеза, епентезис або епентеза, хіазм або хіазма та ін. Деякі терміни утворюють варіанти, репрезентуючи коливання за родовою приналежністю.

У систему термінів лінгвографії повинні ввійти й номінації літературознавства, що окреслюють поетичні жанри, способи творення поезії на основі маніпуляції графічними засобами, напр.: абетковий віри, зорова поезія, паліндром (слова-паліндроми, паліндромні слова, паліндромні фрази), паліндромон та ін.

Отже, графіка, орфографія, пунктуація та лінгвографія загалом формують власну метамову, що репрезентує типові системні парадигматичні зв'язки:

1) полісемії, напр. графіка, порівн.: Графіка - 1) сукупність усіх рукописних та друкованих знаків певної писемності, правил на позначення на письмі відповідності між буквами, їхнім поєднанням і розмежуванням за допомогою пробілів, пунктуаційних знаків, знаків наголосу та ін., а також і фонемами, сполученням фонем, складами, морфемами, словами, синтагмами, реченнями; 2) розділ мовознавства або напрям граматології, що вивчає співвідношення між звуками й літерами. Відомо, що графіку виділяють як окремий розділ мовознавства 3 огляду на те, що існує невідповідність між системою графем та системою фонем певної мови. Точна відповідність літер письма до фонем забезпечує досконалість кожної графічної системи. Існують такі принципи графіки: фонетичний, фонематичний, традииійний. Зазначимо, що основним принципом української графіки є фонематичний. До речі, українську графіку вважають однією 3 найдосконаліших, адже більшість літер українського алфавіту однозначна. Система української графіки включає літери, розділові знаки та апостроф, а також різноманітні прийоми скорочення слів, використання пробілів між словами, великих літер, відступів, різних підкреслень, а в друкованому варіанті тексту - виділення за допомогою різних шрифтів ${ }^{44}$. Пунктуація “(лат. punctuatio, punctum - крапка) - 1) система правил про вживання на письмі розділових знаків; 2) система розділових знаків; 3) розділ

${ }^{43}$ Л.Ф.Українець, зазнач. джер.

44 Украйнська мова: енцииклопедія... с. 111.; О. О. Селіванова, зазнач. джер., с. 108109; А. П. Загнітко, зазнач. джер., т. 1, с. 177. 
мовознавства, що досліджує історію розділових знаків, формування системи розділових знаків, функції розділових знаків, принципи пунктуації тощо"45 та ін.;

2) синонімії: буква, літера; графема, звуко-буква; азбука, алфавіт, абецадло; графеміка, письмо; орфографія, правопис; запинка, кома; єднальний знак, дефіс; інтерпункиія, пунктуачія; “лапки-ялинки”, “фрраниузькі лапки”, “кутові лапки”, “німецькі лапки”, “звичайні лапки”; тире, розділка, павза, пружка; крапка, иятка, хрестик та ін.;

3) омонімії, напр., графон розглядають як стилістичний прийом навмисного викривлення орфографічної норми, що відображає індивідуальні або діалектні порушення фонетичної норми. Значення цього терміна обгрунтувала В. Кухаренко ${ }^{46}$. Учена виокремлює інтеріоральні графони (реалізуються у складі слова) та контактні (реалізуються на межі слів). Первинна функція графонів характерологічна, оскільки вони можуть указувати на приналежність людини до відповідного соціального середовища або відображають ії індивідуальні риси. Вторинна їхня функція зумовлена ідейно-естетичними позиціями автора твору та всім його змістом. Л. Смельянова дещо звужує семантику цього терміна й розглядає його як асоціативний стилістичний прийом фонологічного рівня, що реалізується шляхом порушення орфографічної норми. За такого трактування за межами дослідження залишається низка фонологічних явищ, що не пов'язані із соціально-регіональною диференціацією мовлення, зокрема такі, як дефекти вимови, дитяче мовлення, мовлення в стані афекту, іноземний акцент і под. ${ }^{47}$. Однак наявне й інше розуміння вищенаведеного терміна: його трактують як фігуру мовлення, що відображає відхилення від графічного стандарту чи орфографічної норми з урахуванням усіх графічних засобів виокремлення слів і словосполучень, зокрема й незвичних, однак мотивовані вони стилістикою контексту написання (окреслення) слів (виокремлення за допомогою зміни шрифтів, розрядка, дефісація (,атипове використання дефісу, поділ слова на кілька складів або інші варіанти його залучення, які виходять за межі звичних" ${ }^{48}$, уведення в текст знаків чужої лінгвокультури, уживання великої літери замість малої й навпаки, а також інші графіко-орфографічні альтернативи, зокрема й фігурне розміщення тексту на площині аркуша) $)^{49}$;

4) гіпер-гіпонімії (уточнювальні терміни), напр. лапки - “лапки-ялинки”, “кутові лапки”, дужки - прямі дужки, заокруглені дужки, фігурні дужки;

5) паронімії, графеміка і графетика, графема і графон, форма і форматив, слова-паліндроми (ті, що читаються ззаду наперед, напр., дід, око, nin, наган, Пилип, радар, ротатор) і паліндромні слова (ті, що читаються ззаду наперед, але вже як інші слова, паліндромне слово завжди має свою пару, другим елементом якої може бути й сполучення слів, напр. Рuм - мир, кіт - тік, чемно - он меч і т. п.) та ін.

Терміни графіки та лінгвографії різняться за типовими параметрами, насамперед за: а) походженням: запозичені, напр., дефic, літера, крапка, форматив та ін. і власне украӥнські, напр., буква, буквений запис, иятка та ін.;

\footnotetext{
${ }^{45}$ А. П. Загнітко, зазнач. джер., т. 3, с. 161.

${ }^{46}$ В. А. Кухаренко, Практикум по стилистике английского языка. Seminars in Stylistics, учеб. пособ., Москва 2011.

47 Л. Л. Е м ель я н о в а, Нарушение орфографической нормы как средство создания стилистического эффекта, [в:] „НДВШ. Филол. науки”, Москва 1976, № 1, с. 107-113.

48 Л. Л. Макарук, зазнач. джер., с. 140.

${ }_{49}$ А. П. Сков в родн и ков, Энииклопедический словарь-справочник. Выразительные средства русского языка и речевые ошибки и недочёты, Москва 2009, с. 106-109.
} 
б) активним (кома, крапка, знак оклику та ін.) чи пасивним складом - застарілі, напр., титло, запинка; терміни-неологізми, напр., лексикалізаиія графеми (спосіб творення слова шляхом перетворення графеми на окрему номінативну одиницю) чи семантизація графеми (набуття графемою відповідної семантики), прагматизація графеми (набуття графемою прагматичних смислів, функцій), індивідуально-авторські, напр., викличник (!), наводові знаки («»), павза чи пружка (-), питайник (?), “розділка" (-), середник, або точка із запинкою (;) це терміни, запропоновані В. Сімовичем; емоиіональний розділовий знак термін, запропонований Ж.-Ж. Руссо; в) структурою: одиничні лексеми, напр., лінгвографія, зокрема й складні, напр., графеми-історизми, та словосполучення, напр., буквений запис, графічна лінгвістика, графічна гра, графічний знак, графічний варіант, допоміжна графема, друкований графічний знак та ін.; г) способом номінаціӥ: пряма номінація, напр., кома, крапка, тире, і непряма, що грунтується переважно на метафоризації, напр., "репресована літера", “фірмовий знак” автора. Наявні образні терміни, в основі яких прізвища вчених, що розробляли правописні й графічні варіанти, здійснювали спробу вдосконалювати українську графіку й орфографію, напр., "кулішівка”, “желехівка”, “драгоманівка" та ін., а також терміни, що мотивовані назвами літер, які інколи можуть виражати різні типи конотацій, напр., зневажливо-іронічну — “ярижка" та ін.

Тлумачення деяких термінів на сьогодні ще не усталені й потребують уточнення (напр., графема), а дефініції деяких лише формуються (напр., інтимізувальна графіка чи графеми-інтимізатори).

Нові напрями мовознавства, поліфункційна наукова парадигма вимагають породження нових термінів на окреслення явищ, що пов'язані 3 новими підходами до їхнього вивчення, напр., комунікативний принщип пунктуащіï, прагматичні функиії графеми і под.

Отже, як бачимо, система термінів лінгвографії та графіки розширюється й потребує систематизації. Графіка й лінгвографія, звісно, виробляють і свою систему норм (графічна норма, орфографічна норма, пунктуаційна норма, норми поліграфічні).

Графічна система української мови розширює функції, що зумовлене активним іiї використанням у повсякденній комунікації, дискурсивній практиці українців, домінуванням прагматичного компонента на письмі.

Графеміка, графіка та пунктуація виробляють власну систему регламентованих норм, однак, порушуючи їх, мовець створює прагматичні ефекти. 